\title{
The Physical and Mental Health of Head Start Staff: The Pennsylvania Head Start Staff Wellness Survey, 2012
}

Robert C. Whitaker, MD, MPH; Brandon D. Becker, MPH; Allison N. Herman, MEd, MPH; Rachel A. Gooze, PhD, MPH

Suggested citation for this article: Whitaker RC, Becker BD, Herman AN, Gooze RA. The Physical and Mental Health of Head Start Staff: The Pennsylvania Head Start Staff Wellness Survey, 2012. Prev Chronic Dis 2013;10:130171. DOI: http://dx.doi.org/10.5888/pcd10.130171 国.

PEER REVIEWED

\section{Abstract}

\section{Introduction}

Despite attention to the health of low-income children in Head Start, little is known about the health of adults working for the program. The objective of our study was to compare the physical and mental health of women working in Pennsylvania Head Start programs with the health of US women who have similar sociodemographic characteristics.

\section{Methods}

We used data from a web-based survey in 2012 in which 2,199 of 3,375 (65.2\%) staff in 66 Pennsylvania Head Start programs participated. For the 2,122 female respondents, we determined the prevalence of fair or poor health status, frequent ( $\geq 14 \mathrm{~d} / \mathrm{mo}$ ) unhealthy days, frequent ( $\geq 10 \mathrm{~d} / \mathrm{y}$ ) work absences due to illness, diagnosed depression, and 3 or more of 6 physical health conditions. We compared these prevalences with those found in 2 national samples of employed women of similar age, education, race/ethnicity, and marital status.

\section{Results}

Among Head Start staff, $85.7 \%$ were non-Hispanic white, $62.4 \%$ were married, and $60.3 \%$ had completed college. The prevalence (\% [95\% confidence interval]) of several health indicators was higher in Head Start staff than in the national samples: fair or poor health (14.6\% [13.1\%-16.1\%] vs $5.1 \%[4.5 \%-5.6 \%])$, frequent unhealthy days $(28.3 \%$ [26.3\%-30.2\%] vs 14.5\% [14.1\%-14.9\%]), diagnosed depression (23.5\% [21.7\%-25.3\%] vs 17.6\% [17.1\%-18.0\%]), and 3 or more physical health conditions $(21.8 \%[20.0 \%-23.6 \%]$ vs $12.6 \%[11.7 \%-13.5 \%])$.

\section{Conclusion}

Women working with children in Head Start programs have poorer physical and mental health than do US women who have similar sociodemographic characteristics.

\section{Introduction}

Head Start is the largest federally funded early childhood education program in the United States. Including Early Head Start, which serves children younger than 36 months of age, Head Start reaches nearly 1 million low-income children and their families and employs a staff of more than 200,000, most of whom are women. Staff include managers, classroom teachers, and home-based visitors, along with family service workers, who act as the primary liaison between programs and families. These staff are the key to achieving Head Start's overarching goal of promoting school readiness by addressing children's cognitive, social, emotional, and physical development and health.

For the staff to function well in their work with children and families, they must be well. However, Head Start staff have relatively low wages and social standing and often work under stressful circumstances. Many children in Head Start have multiple social risks, which can contribute to poor self-regulation and disruptive behaviors that interfere with learning and place emotional demands on staff (1). The stress experienced by staff could adversely affect their physical and mental health (2), which in turn could make it harder for staff to serve as models and meet the needs of children and families. 
Despite the potential effect of stress on staff's health and children's outcomes in Head Start, we are not aware of any studies that describe the health of Head Start staff. The objective of this study was to determine the prevalence of physical and mental health conditions, poor health-related quality of life, and health care access in a defined population of Head Start and Early Head Start staff. We also compared the prevalence of these health indicators with the prevalence found in 2 national samples of adults who have similar sociodemographic characteristics.

\section{Methods}

The Pennsylvania Head Start Staff Wellness Survey, conducted during 4 months in spring 2012, was a web-based survey of all staff working in the state's Head Start and Early Head Start programs. Its purpose was to describe the physical health and psychological well-being of the staff and how their health and well-being relates to their functioning at work. The survey was intended to reach the entire staff, including program directors, managers, classroom teachers, home-based visitors, and family service workers. To minimize social desirability bias and ensure confidentiality, the survey was anonymous and voluntary. The research was approved by Temple University's institutional review board.

\section{Participants}

All 91 Head Start and Early Head Start programs in Pennsylvania were invited to participate in the survey. The Pennsylvania Head Start Association, a nonprofit advocacy organization for the state's Head Start and Early Head Start programs and families, helped recruit programs to participate in the survey but was not involved in analyzing the data or reporting the findings. Of the 91 programs, 66 (72.5\%) agreed to participate - 37 of 54 (68.5\%) Head Start programs and 29 of 37 (78.4\%) Early Head Start programs. Eighty percent of nonparticipating programs and $59.1 \%$ of participating programs were in metropolitan areas. From the Office of Head Start's 2011 Program Information Report, which contains data on Head Start and Early Head Start staff aggregated at the program level, we obtained a count of the number of staff in each program. Each participating program director confirmed these numbers before the survey was administered. Directors also reported the number of managers on staff, data which were not available in the Program Information Report. From the 66 participating programs, 2,199 of 3,375 (65.2\%) staff responded to the survey. The education levels and racial/ethnic composition of all staff in the 66 programs were similar to those of the subset of survey respondents.

\section{Survey development}

The survey contained questions on health, psychological well-being, perceived stress, functioning at work, and sociodemographics. This report focuses on health and sociodemographics. These items were modeled on similar items in either the National Health Interview Survey (NHIS) (3) or the Behavioral Risk Factor Surveillance System (BRFSS) (4), allowing for comparison of the findings from our survey with the findings of these national surveys. Our web-based survey was created and hosted by using Qualtrics online survey software (Qualtrics Labs, Inc, Provo, Utah). After pretesting the survey with 11 Head Start staff, we shortened the survey so that it could be completed in 30 to 40 minutes.

\section{Survey administration}

The director of each participating program was responsible for inviting all staff in his or her program to complete the survey, either at or away from work. The research team provided program directors with the online location of the survey website, printed materials to announce and describe the survey, and periodic updates on the response rates of all programs. The research team made no other contact with program staff and offered no monetary incentives to individual staff to participate in the survey. However, programs with a final response rate of at least $75 \%$ were entered into a raffle for 1 of 6 gift cards ranging in value from $\$ 100$ to $\$ 250$. Upon reaching the survey website, each respondent was first required to read a consent form, which explained that only aggregated data would be reported.

\section{Measures}

We computed the prevalence of health indicators in 3 areas: physical and mental health, health-related quality of life, and health care access. The indicators were assessed with questions used in the 2011 version of either NHIS (3) or BRFSS (4).

Physical and mental health: Participants were asked about 6 physical health conditions associated with stress: obesity (5), asthma (6), hypertension (7), diabetes/prediabetes (8), severe headache/migraine (9), and lower back pain (10). Obesity (body mass index $\geq 30 \mathrm{~kg} / \mathrm{m}^{2}$ ) was determined from self-reported height and weight; pregnant women were asked to give their prepregnancy weight. In separate yes/no questions, participants were asked if they had "ever been told by a doctor or other health professional" that they had asthma; hypertension or high blood pressure; diabetes or sugar diabetes (other than during pregnancy); and prediabetes or borderline diabetes. Finally, participants were asked separately whether (yes/no), during the previous 3 months, they had "severe headache or migraine that lasted a whole day or more" and "lower back pain that lasted a whole day or more." We determined the prevalence of each of the 6 physical health conditions and of having 3 or more of these conditions. 
Participants were asked (yes/no) if they had "ever been told by a doctor or other health professional" that they had depression. Although the 20-item Center for Epidemiologic Studies Depression Scale (CES-D) (11) is not part of NHIS or BRFSS, we asked participants to complete the CES-D, and we classified those with a score of 16 or more as depressed $(11,12)$.

Health-related quality of life: Participants were classified as having fair or poor health status according to responses to the question, "Would you say your health in general is poor, fair, good, very good or excellent?" The prevalence of frequent physically unhealthy days, defined as 14 or more physically unhealthy days per month, was based on responses to the question (13), "Thinking about your physical health, which includes physical illness and injury, for how many days during the past 30 days was your physical health not good?” Similarly, the prevalence of frequent mentally unhealthy days, defined as 14 or more mentally unhealthy days per month, was based on the question (13), "Thinking about your mental health, which includes stress, depression, and problems with emotions, for how many days during the past 30 days was your mental health not good?" Finally, the prevalence of 10 or more work absences per year due to illness was based on the following, "During the past 12 months, about how many days did you miss work because of your own illness or injury (do not include maternity leave)?"

Health care access: Participants responded to 3 yes/no questions: “Do you have a personal doctor?" "Have you visited a dentist in the last 12 months?" and "Do you have health insurance coverage?"

\section{Data analysis}

To facilitate a comparison of the prevalence of health indicators between our survey participants and the national samples from NHIS and BRFSS, we analyzed data only for women $(n=2,122)$. We wished to determine the prevalence of each health indicator from a national sample that closely matched our sample on key sociodemographic factors related to health. We first restricted each national data set to employed women aged 18 to 64 who had at least a high school education or general education diploma (GED), characteristics that matched our sample. After applying this restriction, we found sociodemographic differences between our sample and the national samples (Table 1). We then used direct adjustment procedures $(14,15)$ to adjust the prevalence of each health indicator in the national data according to the distribution of our survey participants across strata of age, education, race/ethnicity, and marital status (Table 1). To adjust these national prevalence estimates, we used the survey commands in Stata/SE (version 12, StataCorp LP, College Station, Texas) to take into account the sample weights and variance estimates based on the complex sampling design of these surveys.

\section{Results}

Among survey participants, $55.7 \%$ were aged 40 years or older, $60.3 \%$ finished college, $85.7 \%$ were non-Hispanic white, and $62.4 \%$ were married (Table 1 ). By job category, $48.8 \%$ were teachers (lead or assistant); $14.4 \%$, home-based visitors; $15.0 \%$, family support staff; and $21.8 \%$, managers.

All 6 physical health conditions were more common among Head Start staff than among the national sample (Table 2). Although 23.6\% of Head Start staff reported having none of the 6 physical health conditions, 21.8\% reported having 3 or more (Table 2). In the national sample, 35.1\% reported having none of the 6 physical health conditions, and $12.6 \%$ reported having 3 or more. The prevalence of diagnosed depression was higher among Head Start staff than among the national sample. Based on responses to the CES-D, 24.4\% of Head Start staff were depressed, and of these, 55.8\% reported not ever receiving a diagnosis of depression. We found depression indicated by CES-D or diagnosis in $37.0 \%$ of Head Start staff.

Fair or poor health status was almost 3 times more common among Head Start staff than among the national sample (Table 2). Among Head Start staff, having frequent mentally unhealthy days was almost twice as common as having frequent physically unhealthy days. Although the prevalence of frequent unhealthy days was higher among Head Start staff than among the national sample, the prevalence of 10 or more days per year of work absence due to illness was not significantly higher. Among Head Start staff, $48.5 \%$ of those who reported frequent physically unhealthy days also reported frequent mentally unhealthy days, compared with $33.0 \%$ in the national sample. Among Head Start staff who reported frequent physically unhealthy days, $24.2 \%$ reported 10 or more days per year of work absences due to illness; among those who reported frequent mentally unhealthy days, $12.9 \%$ had 10 or more days per year of work absences due to illness. When we further restricted the national samples to those with an annual household income below $\$ 50,000$, which is in the upper salary range reported for Head Start managers in Pennsylvania, the findings shown in Table 2 did not change.

Among Head Start staff, the prevalence of frequent mentally unhealthy days, frequent physically unhealthy days, and 10 or more days per year of work absence due to illness was greater among those with 3 or more physical health conditions than among those with fewer than 3 conditions (Table 3). The prevalence of frequent unhealthy days and work absences was also greater among Head Start staff who were classified as depressed according to the CES-D than among those who were not so classified (Table 3). Having 3 or more physical health conditions was more common 
among those with CES-D-defined depression than among those without it (31.5\% vs 18.8\%; odds ratio, 1.98; $95 \%$ confidence interval, 1.58-2.48).

Nearly all Head Start staff (>96\%) reported having health insurance and a personal doctor, a greater percentage than in the national sample. Almost $25 \%$ of Head Start staff had not visited a dentist in the previous year, which was also comparable with findings for the national sample.

\section{Discussion}

Among women working in Head Start and Early Head Start Programs in Pennsylvania, the prevalence of physical and mental health conditions, fair or poor health status, and frequent mentally and physically unhealthy days were higher than among employed women in a national sample of women of similar age, education, race/ethnicity, and marital status. We identified only 1 US study on the prevalence of physical health indicators within a population-based sample of staff working in early childhood care and education settings (16). In that 1993 study of 446 early childhood workers in Wisconsin, the prevalences of fair or poor health, back pain, and headache were lower than were those in our study. However, the data are not directly comparable because the Wisconsin survey used different questions. In a more recent survey of 168 early childhood workers in Wellington, New Zealand, the investigators used the same questions used in the Wisconsin survey and showed lower prevalences of fair or poor health, back pain, and headache than those found in our study (17). In our study, 24.4\% of Head Start staff had clinically significant depressive symptoms (CES-D score $\geq 16$ ). A national study of early childhood care and education staff used the same measure and found a prevalence of 9.4\% (18). The difference may have resulted from our survey being anonymous or our sample having only staff working in Head Start and Early Head Start.

Our study had several limitations. The survey respondents may not be representative of all Head Start and Early Head Start staff working in Pennsylvania. Because some programs in the state did not participate in the survey, staff working in urban programs, particularly in Philadelphia, were underrepresented. Within the 66 participating programs, the education level and racial/ethnic composition of the participating staff were similar to those of the whole staff. However, nonresponse bias due to a healthy-volunteer effect within participating programs may have led to an underestimate of the prevalence of health indicators (19). Response rates may have been higher if we had identified individual staff and provided them reminders and monetary incentives. However, we felt that an anonymous survey would provide greater assurance of confidentiality and, therefore, increase participation and reduce social desirability bias. Finally, the differences in the prevalence of health indicators between Head Start staff and the national samples may have been overestimated because we did not collect data on household income and size and could not adjust for it. However, all salaries in Head Start are relatively low, with the average Head Start teacher in Pennsylvania earning approximately $\$ 26,000$ a year.

The overall goal of Head Start and Early Head Start is to increase the school readiness of economically and socially disadvantaged children. Achieving this goal depends on the functioning of the staff, but the staff must be well - both physically and mentally - to optimally use their skills and training. The healthy development of children in all early childhood care and education settings relies not only on adults being physically and emotionally engaged but also on being consistently present at work (20). Almost 30\% of Head Start staff reported feeling physically or mentally unhealthy more than 2 weeks in the previous month, and almost $10 \%$ reported missing 2 or more weeks of work in the previous year due to illness.

The high prevalence of depressive symptoms found in this study and its potential impacts on children in Head Start and Early Head Start requires further study. Although research finds that maternal depression can adversely impact young children (21,22), similar evidence does not exist about the impact of depression among early childhood educators on children's outcomes. Symptoms of depression in early childhood staff are associated with lower sensitivity and increased withdrawal in adult-child interactions (18). Staff's symptoms of depression may also interfere with the development of healthy self-regulation in children, which could affect school readiness (23).

In addition, the physical health of Head Start staff is important, especially given the increasing attention in early childhood care and education programs to the role of movement in children's learning and health (24). This emphasis on movement reflects a long-standing appreciation of how young children learn through movement (25), and the potential contribution of movement to preventing early childhood obesity. Obesity and its comorbidities, along with back pain and headache, may impair the ability of Head Start staff to model healthy movement and engage children by moving with them. To address childhood obesity, the Office of Head Start implemented a nationwide program enhancement (I Am Moving, I Am Learning) that includes activities to improve the diet and physical activity behaviors of the Head Start staff (26). In child care centers outside Head Start, similar efforts with staff have been made (27).

Improving child outcomes in Head Start and Early Head Start may require more attention to the health and well-being of the staff. Some promising approaches to improving staff wellness through professional development and staff training models include mindfulness-based stress-reduction techniques (28). Such approaches have already been 
applied in other professions, such as health care, public safety, and social work, in which high demands are placed on staff who must be physically and mentally well to serve others $(29,30)$. Bibliotherapy, the use of books or other reading materials for help in solving personal problems, is another promising approach to addressing staff wellness because it is low-cost and avoids stigma (31). In the area of physical health, worksite models for teachers are emerging as a component of school-based obesity prevention programs (32).

In Head Start and Early Head Start, as well as in other early childhood care and education programs, staff are the necessary link between program content and children's outcomes. However, our data suggest that the women working with children in Head Start and Early Head Start have poorer physical and mental health than do US women with similar sociodemographic characteristics. More investments may be required to support the health and well-being of those adults to whom the public entrusts children's development and learning outside the home.

\section{Acknowledgments}

The efforts of Rachel A. Gooze were supported by a University Fellowship from the Graduate School at Temple University, Philadelphia, Pennsylvania. We thank all the Head Start and Early Head Start staff who completed the survey; the Pennsylvania Head Start Association for assisting with the recruitment of the Head Start and Early Head Start programs that participated in the study; Amy Requa, MSN, CRNP, and Bruce S. McEwen, PhD, for their encouragement and advice on designing and implementing the study; Khushi Malhotra, MPH, MSW, for her assistance in selecting the instruments included in the survey; David F. Tucker for his technical assistance on the web-based survey design; and Kenneth C. Schoendorf, MD, MPH, for his technical advice on the data analysis.

\section{Author Information}

Corresponding Author: Robert C. Whitaker, MD, MPH, Temple University, Center for Obesity Research and Education, 3223 North Broad St, Ste 175, Philadelphia, PA 19140. Telephone: 215-707-8676. E-mail: rwhitaker@temple.edu.

Author Affiliations: Brandon D. Becker, Allison N. Herman, Rachel A. Gooze, Temple University, Philadelphia, Pennsylvania. Ms Herman is now at the Children's Hospital of Philadelphia, Philadelphia, Pennsylvania. Dr Gooze is now at Child Trends, Bethesda, Maryland.

\section{References}

1. McClelland MM, Cameron CE, Connor CM, Farris CL, Jewkes AM, Morrison FJ. Links between behavioral regulation and preschoolers' literacy, vocabulary, and math skills. Dev Psychol 2007;43(4):947-59. CrossRef 圈 PubMed 圈

2. Nixon AE, Mazzola JJ, Bauer J, Krueger JR, Spector PE. Can work make you sick? A meta-analysis of the relationships between job stressors and physical symptoms. Work Stress 2011;25(1):1-22. CrossRef 因

3. Centers for Disease Control and Prevention. National Health Interview Survey: questionnaires, datasets, and related documentation, 1997 to the present.

http://www.cdc.gov/nchs/nhis/quest_data_related_1997_forward.htm. Accessed May 19, 2013.

4. Centers for Disease Control and Prevention, Office of Surveillance, Epidemiology, and Laboratory Services. Behavioral Risk Factor Surveillance System: questionnaires.

http://www.cdc.gov/brfss/questionnaires/english.htm. Accessed May 19, 2013.

5. Wardle J, Chida Y, Gibson EL, Whitaker KL, Steptoe A. Stress and adiposity: a meta-analysis of longitudinal studies. [Published erratum in: Obesity (Silver Spring) 2011;19(6):1315]. Obesity (Silver Spring) 2011;19(4):771-8. CrossRef圈 PubMed 圈

6. Wisnivesky JP, Lorenzo J, Feldman JM, Leventhal H, Halm EA. The relationship between perceived stress and morbidity among adult inner-city asthmatics. J Asthma 2010;47(1):100-4. CrossRef 国 PubMed $\mathrm{E}$

7. Rozanski A, Blumenthal JA, Kaplan J. Impact of psychological factors on the pathogenesis of cardiovascular disease and implications for therapy. Circulation 1999;99(16):2192-217. CrossRef : PubMed 圈

8. Black PH. The inflammatory response is an integral part of the stress response: implications for atherosclerosis, insulin resistance, type II diabetes and metabolic syndrome X. Brain Behav Immun 2003;17(5):350-64. CrossRef 圈PubMed 圈

9. Nash JM, Thebarge RW. Understanding psychological stress, its biological processes, and impact on primary headache. Headache 2006;46(9):1377-86. CrossRef 国 PubMed 圈

10. Linton SJ. A review of psychological risk factors in back and neck pain. Spine 2000;25(9):1148-56. CrossRef园 PubMed因 
11. Radloff LS. The CES-D scale. Appl Psychol Meas 1977;1(3):385-401. CrossRef 国

12. Comstock GW, Helsing KJ. Symptoms of depression in two communities. Psychol Med 1976;6(4):551-63. CrossRef 圈 PubMed 圂

13. Moriarty DG, Zack MM, Kobau R. The Centers for Disease Control and Prevention's Healthy Days Measures population tracking of perceived physical and mental health over time. Health Qual Life Outcomes 2003;1:37. CrossRef 圈 PubMed 图

14. Klein RJ, Schoenborn CA. Age adjustment using the 2000 projected U.S. population. Statistical Notes Reports. No. 20. Hyattsville (MD): National Center for Health Statistics; 2001.

15. Curtin LR, Klein RJ. Direct standardization (age-adjusted death rates). Healthy People 2000 Stat Notes 1995. http://www.cdc.gov/nchs/data/statnt/statnto6rv.pdf. Accessed September 12, 2013.

16. Gratz RR, Claffey A. Adult health in child care: health status, behaviors, and concerns of teachers, directors, and family child care providers. Early Child Res Q 1996;11(2):243-67. CrossRef 圈

17. McGrath BJ, Huntington AD. The health and wellbeing of adults working in early childhood education. Aust $J$ Early Child 2007;32(3):33-8.

18. Hamre BK, Pianta RC. Self-reported depression in nonfamilial caregivers: prevalence and associations with caregiver behavior in child-care settings. Early Child Res Q 2004;19(2):297-318. CrossRef 圈

19. Delgado-Rodríguez M, Llorca J. Bias. J Epidemiol Community Health 2004;58(8):635-41. CrossRef 圈 PubMed 国

20. Howes $\mathrm{C}$, Hamilton $\mathrm{CE}$. The changing experience of child care: changes in teachers and in teacher-child relationships and children's social competence with peers. Early Child Res Q 1993;8(1):15-32. CrossRef 圈

21. Goodman SH, Rouse MH, Connell AM, Broth MR, Hall CM, Heyward D. Maternal depression and child psychopathology: a meta-analytic review. Clin Child Fam Psychol Rev 2011;14(1):1-27. CrossRef 圈 PubMed 圈

22. National Institute of Child Health and Human Development, Early Child Care Research Network. Chronicity of maternal depressive symptoms, maternal sensitivity, and child functioning at 36 months. Dev Psychol 1999;35 (5):1297-310. CrossRef 国 PubMed 圈

23. Ursache A, Blair C, Raver CC. The promotion of self-regulation as a means of enhancing school readiness and early achievement in children at risk for school failure. Child Dev Perspect 2012;6(2):122-8. CrossRef

24. Copeland KA, Kendeigh CA, Saelens BE, Kalkwarf HJ, Sherman SN. Physical activity in child-care centers: do teachers hold the key to the playground? Health Educ Res 2012;27(1):81-100. CrossRef 圈 PubMed 圈

25. Thelen E, Smith LB. A dynamic systems approach to the development of cognition and action. Cambridge (MA): The MIT Press; 1994.

26. Administration for Children and Families. Efforts to meet children's physical activity and nutritional needs: findings from the I Am Moving, I Am Learning implementation evaluation: final report. Washington (DC): US Department of Health and Human Services; 2010.

27. Gosliner WA, James P, Yancey AK, Ritchie L, Studer N, Crawford PB. Impact of a worksite wellness program on the nutrition and physical activity environment of child care centers. Am J Health Promot 2010;24(3):186-9. CrossRef 圈 PubMed 圈

28. Jennings PA, Snowberg KE, Coccia MA, Greenberg MT. Improving classroom learning environments by Cultivating Awareness and Resilience in Education (CARE): results of two pilot studies. J Classr Interact 2011;46 (1):37-48.

29. Irving JA, Dobkin PL, Park J. Cultivating mindfulness in health care professionals: a review of empirical studies of mindfulness-based stress reduction (MBSR). Complement Ther Clin Pract 2009;15(2):61-6. CrossRef 圈 PubMed 因

30. Shapiro SL, Brown KW, Biegel GM. Teaching self-care to caregivers: effects of mindfulness-based stress reduction on the mental health of therapists in training. Train Educ Prof Psychol 2007;1(2):105-15. CrossRef

31. Jeffcoat T, Hayes SC. A randomized trial of ACT bibliotherapy on the mental health of $\mathrm{K}-12$ teachers and staff. Behav Res Ther 2012;50(9):571-9. CrossRef 罡 PubMed 国

32. Webber LS, Rice JC, Johnson CC, Rose D, Srinivasan SR, Berenson GS. Cardiovascular risk factors and physical activity behavior among elementary school personnel: baseline results from the ACTION! worksite wellness program. J Sch Health 2012;82(9):410-6. CrossRef 国 PubMed 圈

\section{Tables}


Preventing Chronic Disease | The Physical and Mental Health of Head Start Staff: The Pe... Page 7 of 9

Table 1. Sociodemographic Characteristics of Pennsylvania Head Start Staff Survey Participants in 2012 and National Reference Populations in 2011

\begin{tabular}{|c|c|c|c|c|c|c|}
\hline \multirow[b]{2}{*}{ Characteristic } & \multicolumn{2}{|c|}{$\begin{array}{l}\text { Head Start Staff }(\mathrm{N}= \\
\qquad 2,122)\end{array}$} & \multicolumn{2}{|c|}{$\begin{array}{c}\text { NHIS } 2011 \\
9,118)\end{array}(\mathrm{N}=$} & \multicolumn{2}{|c|}{$\begin{array}{c}\text { BRFSS } 2011(\mathrm{~N}= \\
123,699)\end{array}$} \\
\hline & na & $\%(95 \% \mathrm{CI})$ & nb & $\%(95 \% \mathrm{CI})$ & nc & $\%(95 \% \mathrm{CI})$ \\
\hline \multicolumn{7}{|l|}{ Age, y } \\
\hline $18-29$ & 366 & $17.8(16.1-19.4)$ & 2,324 & $26.8(25.4-28.1)$ & 13,825 & $22.0(21.4-22.6)$ \\
\hline $30-39$ & 546 & $26.5(24.6-28.4)$ & 2,162 & $21.3(20.4-22.3)$ & 22,528 & $22.2(21.8-22.7)$ \\
\hline $40-49$ & 497 & $24.1(22.3-26.0)$ & 2,069 & $23.0(21.9-24.0)$ & 31,484 & $25.2(24.8-25.7)$ \\
\hline$\geq 50$ & 651 & $31.6(29.6-33.6)$ & 2,563 & $28.9(27.8-30.1)$ & 55,862 & $30.6(30.1-31.0)$ \\
\hline \multicolumn{7}{|c|}{ Highest education level } \\
\hline High school or GED & 421 & $20.0(18.3-21.7)$ & 2,098 & $23.3(22.2-24.4)$ & 30,106 & $27.0(26.5-27.5)$ \\
\hline Some college & 415 & $19.7(18.0-21.4)$ & 3,552 & $38.4(37.0-39.7)$ & 37,547 & $36.3(35.8-36.9)$ \\
\hline $\begin{array}{l}\text { Bachelor's degree or } \\
\text { higher }\end{array}$ & 1,270 & $60.3(58.2-62.4)$ & 3,468 & $38.3(36.9-39.8)$ & 56,046 & $36.7(36.1-37.2)$ \\
\hline \multicolumn{7}{|l|}{ Race/ethnicity } \\
\hline Non-Hispanic white & 1,804 & $85.7(84.2-87.2)$ & 5,535 & $70.5(69.2-71.8)$ & 96,375 & $69.7(69.1-70.2)$ \\
\hline Non-Hispanic black & 126 & $6.0(5.0-7.0)$ & 1,532 & $12.8(11.9-13.7)$ & 11,365 & $12.5(12.1-12.9)$ \\
\hline Non-Hispanic other & 53 & $2.5(1.8-3.1)$ & 737 & $6.2(5.6-6.8)$ & 7,036 & $7.2(6.9-7.6)$ \\
\hline Hispanic (any race) & 123 & $5.8(4.8-6.8)$ & 1,314 & $10.5(9.8-11.2)$ & 8,143 & $10.6(10.2-11.0)$ \\
\hline \multicolumn{7}{|l|}{ Relationship status } \\
\hline Married & 1,310 & $62.4(60.3-64.4)$ & 3,902 & $52.9(51.6-54.2)$ & 71,634 & $52.6(52.1-53.2)$ \\
\hline Not married & 791 & $37.6(35.6-39.7)$ & 5,195 & $47.1(45.8-48.4)$ & 51,598 & $47.4(46.8-47.9)$ \\
\hline
\end{tabular}

Abbreviations: NHIS, National Health Interview Survey; BRFSS, Behavioral Risk Factor Surveillance System; CI, confidence interval; GED, general educational diploma.

a Data were missing for age $(n=62)$, race/ethnicity $(n=16)$, relationship status $(n=21)$, and education level $(n=16)$.

b Unweighted n's and weighted percentages among employed women aged 18 to 64 whose highest education level was at least high school or GED. Data were missing on relationship status $(n=21)$.

c Unweighted n's and weighted percentages among employed women aged 18 to 64 whose highest education level was at least high school or GED. Data were missing on race/ethnicity $(n=780)$ and relationship status $(n=467)$.

Table 2. Prevalence of Heath Indicators Among Pennsylvania Head Start Staff Survey Participants $(\mathrm{N}=2,122)$ in 2012 and a National Reference Population in 2011a

\begin{tabular}{|l|r|r|r|}
\hline Health Indicator & $\begin{array}{r}\text { Head Start Staff, \% } \\
\text { (95\% CI) }\end{array}$ & $\begin{array}{r}\text { National Reference, \% } \\
\text { (95\% CI) }\end{array}$ & $\begin{array}{c}\text { Difference, \% } \\
\mathbf{( 9 5 \%} \text { CI) }\end{array}$ \\
\hline Physical health & $32.2(30.2-34.2)$ & $21.6(20.4-22.8)$ & $10.6(8.3-12.9)$ \\
\hline Severe headache or migraine & $36.9(34.9-40.0)$ & $23.9(22.6-25.1)$ & $13.0(10.6-15.4)$ \\
\hline Lower back pain & $37.1(34.9-39.3)$ & $27.3(26.0-28.6)$ & $9.8(7.3-12.3)$ \\
\hline Obesity & $18.7(17.0-20.3)$ & $13.6(12.5-14.7)$ & $5.0(3.1-7.0)$ \\
\hline Asthma & $22.3(20.5-24.0)$ & $18.1(17.0-19.2)$ & $4.1(2.0-6.2)$ \\
\hline High blood pressure & $11.9(10.5-13.3)$ & $7.8(7.1-8.6)$ & $4.1(2.5-5.6)$
\end{tabular}




\begin{tabular}{|c|c|c|c|}
\hline Health Indicator & $\begin{array}{c}\text { Head Start Staff, \% } \\
(95 \% \mathrm{CI})\end{array}$ & $\begin{array}{c}\text { National Reference, } \% \\
(95 \% \mathrm{CI})\end{array}$ & $\begin{array}{l}\text { Difference, } \% \\
\quad(95 \% \mathrm{CI})\end{array}$ \\
\hline$\geq 3$ Physical health conditions & $21.8(20.0-23.6)$ & $12.6(11.7-13.5)$ & $9.2(7.3-11.2)$ \\
\hline \multicolumn{4}{|l|}{ Mental health } \\
\hline $\begin{array}{l}\text { Depression diagnosed by health } \\
\text { professional }\end{array}$ & $23.5(21.7-25.3)$ & $17.6(17.1-18.0)$ & $5.9(4.0-7.8)$ \\
\hline \multicolumn{4}{|l|}{ Health-related quality of life } \\
\hline Fair or poor health status & $14.6(13.1-16.1)$ & $5.1(4.5-5.6)$ & $9.5(7.9-11.1)$ \\
\hline $\begin{array}{l}\text { Frequent physically unhealthy days ( } \geq 14 \\
d / m o \text { ) }\end{array}$ & $10.1(8.8-11.4)$ & $5.9(5.6-6.1)$ & $4.2(2.9-5.5)$ \\
\hline $\begin{array}{l}\text { Frequent mentally unhealthy days ( } \geq 14 \\
\mathrm{~d} / \mathrm{mo} \text { ) }\end{array}$ & $18.0(16.4-19.7)$ & $9.5(9.2-9.8)$ & $8.5(6.8-10.2)$ \\
\hline $\begin{array}{l}\text { Frequent physically or mentally unhealthy } \\
\text { days }(\geq 14 \mathrm{~d} / \mathrm{mo})\end{array}$ & $28.3(26.3-30.2)$ & $14.5(14.1-14.9)$ & $13.7(11.8-15.7)$ \\
\hline Work absences due to illness ( $\geq 10 \mathrm{~d} / \mathrm{y})$ & $8.6(7.4-9.8)$ & $7.4(6.7-8.2)$ & $1.2(-0.2$ to 2.6$)$ \\
\hline \multicolumn{4}{|l|}{ Health care access } \\
\hline Has personal doctor & $96.5(95.7-97.3)$ & $86.4(86.0-86.8)$ & $10.1(9.2-11.0)$ \\
\hline Has health insurance & $96.4(95.6-97.2)$ & $89.5(88.8-90.3)$ & $6.9(5.8-8.0)$ \\
\hline Has visited dentist in last 12 months & $76.4(74.6-78.3)$ & $76.2(75.0-77.5)$ & $0.2(-2.0$ to 2.4$)$ \\
\hline
\end{tabular}

Abbreviation: CI, confidence interval.

a All national estimates were obtained from the National Health Interview Survey (NHIS) 2011, except for the following: diagnosed depression; number of physically unhealthy days, mentally unhealthy days, and physically or mentally unhealthy days; and access to a personal doctor. Data on these latter items were obtained from the Behavioral Risk Factor

Surveillance System (BRFSS) 2011. Weighted percentages were from a restricted sample from either NHIS $(n=9,118)$ or BRFSS $(n=123,699)$. Both national samples were restricted to employed women aged 18 to 64 years whose highest

education level was at least high school or a general education diploma; to match the Head Start sample, percentages were further adjusted for age, race/ethnicity, education level, and marital status.

Table 3. Prevalence of Unhealthy Days and Absences, by Number of Physical Conditions and CES-D Score Among Pennsylvania Head Start Staff, 2012

\begin{tabular}{|c|c|c|c|c|c|c|}
\hline \multirow[b]{2}{*}{ Health Indicator } & \multicolumn{3}{|c|}{ Number of Physical Conditionsa } & \multicolumn{3}{|c|}{ CES-D Scoreb } \\
\hline & $\begin{array}{c}\geq 3 \\
\text { Conditions, \% } \\
(n=459)\end{array}$ & $\begin{array}{l}<3 \text { Conditions, } \\
\%(n=1,645)\end{array}$ & $\begin{array}{l}\text { Odds Ratio } \\
(95 \% \\
\text { Confidence } \\
\text { Interval) }\end{array}$ & $\begin{array}{c}\text { Score } \\
\geq 16, \% \\
(n= \\
513)\end{array}$ & $\begin{array}{c}\text { Score } \\
<16, \% \\
(n= \\
1,589)\end{array}$ & $\begin{array}{l}\text { Odds Ratio } \\
\text { (95\% } \\
\text { Confidence } \\
\text { Interval) }\end{array}$ \\
\hline $\begin{array}{l}\geq 14 \text { Physically } \\
\text { unhealthy } \\
\text { days/month }\end{array}$ & 19.9 & 7.2 & $3.18(2.37-4.29)$ & 18.1 & 7.3 & $2.78(2.07-3.74)$ \\
\hline $\begin{array}{l}\geq 14 \text { Mentally } \\
\text { unhealthy } \\
\text { days/month }\end{array}$ & 26.6 & 15.6 & $1.96(1.53-2.51)$ & 51.7 & 7.2 & $\begin{array}{r}13.83(10.66- \\
17.94)\end{array}$ \\
\hline $\begin{array}{l}\text { Absent from work } \\
\geq 10 \text { days/year } \\
\text { due to illness }\end{array}$ & 16.0 & 6.6 & $2.72(1.98-3.73)$ & 12.8 & 7.3 & $1.87(1.36-2.58)$ \\
\hline
\end{tabular}

Abbreviations: CES-D, Center for Epidemiologic Studies Depression Scale.

a Number of physical conditions among the following 6: obesity (body mass index $\geq 30 \mathrm{~kg} / \mathrm{m}^{2}$ based on self-reported height and weight), diagnosed asthma, diagnosed hypertension, diagnosed diabetes/prediabetes, severe headache/migraine in last 3 months, and lower back pain in last 3 months. Data on the physical health conditions score were missing for 18 of 2,122 participants.

b Data on the CES-D were missing for 20 of 2,122 participants. 
Preventing Chronic Disease | The Physical and Mental Health of Head Start Staff: The Pe... Page 9 of 9

\section{Comment on this article at PCD Dialogue}

Learn more about PCD's commenting policy

The opinions expressed by authors contributing to this journal do not necessarily reflect the opinions of the U.S. Department of Health and Human Services, the Public Health Service, the Centers for Disease Control and Prevention, or the authors' affiliated institutions.

견 The RIS file format is a text file containing bibliographic citations. These files are best suited for import into bibliographic management applications such as EndNote 娄, Reference Manager 国, and ProCite 国. A free trial download is available at each application's web site.

For Questions About This Article Contact pcdeditor@cdc.gov

Page last reviewed: November 21, 2013

Page last updated: November 21, 2013

Content source: National Center for Chronic Disease Prevention and Health Promotion

Centers for Disease Control and Prevention 1600 Clifton Rd. Atlanta, GA 30333, USA 800-CDC-INFO (800-232-4636) TTY: (888) 232-6348 - Contact CDC-INFO 